\title{
Theoretical study, synthesis, kinetics and mechanistic investigation of a stable phosphorus ylide in the presence of methyl carbamate as a $\mathrm{NH}$-acid
}

\author{
Mohammad Zakarianejad, ${ }^{\text {a }}$ Hojjat Ghasempour, ${ }^{\text {b }}$ Sayyed Mostafa Habibi-Khorassani, ${ }^{c}$ \\ Malek Taher Maghsoodlou, ${ }^{\mathrm{c}}$ Batoul Makiabadi, ${ }^{\mathrm{d}}$ Mahmoud Nassiri, ${ }^{\mathrm{e}}$ Zahra Ghahghayi, \\ and Alireza Abedi ${ }^{\mathrm{c}}$ \\ ${ }^{a}$ Department of Chemistry, Payam Noor University, 19395-3697, Tehran, Iran \\ ${ }^{b}$ Department of Chemistry, Bardsir Branch, Islamic Azad University, 14527, Bardsir, Iran \\ ${ }^{c}$ Department of Chemistry, The University of Sistan and Baluchestan, 98135-674, Zahedan, Iran \\ ${ }^{d}$ Department of Chemical Engineering, Sirjan University of Technology, \\ 7813733385 Sirjan, Iran \\ ${ }^{e}$ Maritime Department, The University of Chabahar, 25458-4789, Chabahar, Iran \\ E-mail:habibi_khorassani@yahoo.com
}

\begin{abstract}
Triphenylphosphine reacts with dialkyl acetylenedicarboxylates in the presence of methyl carbamate to generate stable phosphorus ylides. These ylides exist in solution as a mixture of two geometrical isomers as a result of restricted rotation around the carbon-carbon partial double bond resulting from conjugation of the ylide moiety with the adjacent carbonyl group. Quantum mechanical calculations were employed to check the stability of the two geometrical isomers. To determine the kinetic parameters and mechanistic investigation of the reactions, they were monitored by UV spectrophotometry. Useful information was obtained from studies of the effect of solvent, the structure of reactants (different alkyl groups within the dialkyl acetylenedicarboxylates), and also the concentration of reactants, on the rate of reactions. The proposed mechanism was confirmed according to the obtained experimental results, and a steady state approximation. The first $\left(k_{2}\right)$ and third $\left(k_{3}\right)$ steps of the reactions were recognized as the ratedetermining and fast steps, respectively, on the basis of experimental data.
\end{abstract}

Keywords: Kinetic study, acetylenic esters, theoretical study, stable phosphorus ylides

\section{Introduction}

In recent years there has been increasing interest in the synthesis of organophosphorus compounds. $^{1-14}$ A large number of methods have appeared describing novel syntheses of organophosphorus compounds. ${ }^{1,2}$ There are many studies on the reaction between trivalent 
phosphorus nucleophiles and $\alpha, \beta$-unsaturated carbonyl compounds in the presence of a proton source such as an alcohol or phenol. ${ }^{5}$

As part of our current studies on the development of new routes to stable phosphorus ylides, ${ }^{11-14}$ we now describe the reaction between triphenylphosphine $\mathbf{1}$ and dialkyl acetylenedicarboxylates $\mathbf{2}$ in the presence of methyl carbamate $\mathbf{3}$ which leads to the corresponding stable phosphorus ylids $\mathbf{4}$ in fairly high yield. These ylides usually exist as a mixture of the two geometrical isomers, although some are only found as one isomer. Assignment of the relative stability of the ( $Z$ )- and $E$-isomers is possible in phosphorus ylides by experimental methods such as ${ }^{1} \mathrm{H},{ }^{13} \mathrm{C}$ NMR and IR spectroscopy and mass spectrometry. Quantum mechanical calculations have been performed for comparison with the experimental data in order to gain a better understanding of the most important geometrical parameters and also relative energies of the $(Z)$ - and $E$-geometrical isomers.

\section{Results and Discussion}

\section{Synthesis}

In the current work, the synthesis of stable phosphorus ylides $\mathbf{4 a , b}$ was carried out using the reaction between triphenylphosphine (1) and dialkyl acetylenedicarboxylates (2) in the presence of methyl carbamate (3) in acetone at room temperature in fairly high yield (Scheme 1$)$. The ${ }^{1} \mathrm{H}$ and ${ }^{13} \mathrm{C}$ NMR spectra of the crude product clearly indicated the formation of compounds $\mathbf{4}(\mathbf{a}, \mathbf{b})$. No products other than $\mathbf{4}(\mathbf{a}, \mathbf{b})$ could be detected by NMR spectroscopy. The structures of compounds $4(\mathbf{a}, \mathbf{b})$ were deduced from their IR, ${ }^{1} \mathrm{H},{ }^{13} \mathrm{C}$ and ${ }^{31} \mathrm{P}$ NMR spectra. Although the presence of the ${ }^{31} \mathrm{P}$ nucleus complicates both the ${ }^{1} \mathrm{H}$ and ${ }^{13} \mathrm{C}$ NMR spectra of $4 \mathbf{a}$, it helps in assignment of the signals by long-range couplings with the ${ }^{1} \mathrm{H}$ and ${ }^{13} \mathrm{C}$ nuclei (see Experimental section).

The ${ }^{1} \mathrm{H},{ }^{13} \mathrm{C}$, and ${ }^{31} \mathrm{P}$ NMR spectra of ylides $\mathbf{4}(\mathbf{a}, \mathbf{b})$ are consistent with the presence of two geometrical isomers. The ylide moiety of these compounds is strongly conjugated with the adjacent carbonyl group and rotation around the partial double bond in $(E)-\mathbf{4}(\mathbf{a}, \mathbf{b})$ and $(Z)-\mathbf{4}(\mathbf{a}, \mathbf{b})$ geometrical isomers is slow on the NMR time-scale at ambient temperature (Scheme 1). On the basis of the well-established chemistry of trivalent phosphorus nucleophiles, ${ }^{3-7}$ it is reasonable to assume that phosphorus ylide 4 results from the initial addition of triphenylphosphine to the acetylenic esters and subsequent protonation of the 1:1 adduct by the methyl carbamate to form phosphoranes 4. The ${ }^{1} \mathrm{H}$ NMR spectrum of $4 \mathbf{a}$ showed six sharp lines at $\delta=3.15,3.57,3.61$, $3.63,3.68$ and $3.72 \mathrm{ppm}$ arising from methoxy protons. Methine protons appeared as a broad peak at $4.27 \mathrm{ppm}\left(\mathrm{Ph}_{3} \mathrm{P}-\mathrm{CH}-\mathrm{NH}\right)$ for the major and minor geometrical isomer. Amino protons appeared as two doublet peaks at $6.58 \mathrm{ppm}\left(1 \mathrm{H}, \mathrm{d},{ }^{3} J_{\mathrm{HH}}=9.2 \mathrm{~Hz}, \mathrm{Ph}_{3} \mathrm{P}-\mathrm{CH}-\mathrm{NH}\right)$ and $5.93 \mathrm{ppm}$ $\left(1 \mathrm{H}, \mathrm{d},{ }^{3} J_{\mathrm{HH}}=8.8 \mathrm{~Hz}, \mathrm{Ph}_{3} \mathrm{P}-\mathrm{CH}-\mathrm{NH}\right)$, for the major and minor isomers respectively. The aromatic protons appeared as a multiplet at $\delta=7.29-7.74 \mathrm{ppm}$. The ${ }^{13} \mathrm{C}$ NMR spectrum of $4 \mathbf{a}$ displayed 24 distinct resonances in a good agreement with the mixture of the two geometrical 
isomers. The ${ }^{1} \mathrm{H}$ and ${ }^{13} \mathrm{C}$ NMR spectra of compound $\mathbf{4 b}$ is similar to that of $\mathbf{4 a}$, except for the signals from the ester group, which appear as characteristic resonance lines with the corresponding chemical shifts. The structural assignments for compounds $\mathbf{4}(\mathbf{a}, \mathbf{b})$ were made on the basis of the ${ }^{1} \mathrm{H}$ and ${ }^{13} \mathrm{C}$ NMR spectra that were supported by their IR spectra. The carbonyl region of the spectra exhibits three distinct IR absorption bands for each compound. Of special interest is the ester absorption at $1725-1615 \mathrm{~cm}^{-1}$. Conjugation of negative charge in ylide region with the carbonyl of ester group within the structure of ylide accounts for the reduction in the frequency of the carbonyl absorption band $\left(\mathrm{Ph}_{3} \mathrm{P}^{+}-\mathrm{C}=\mathrm{C}-\mathrm{O}^{-}\right)$.

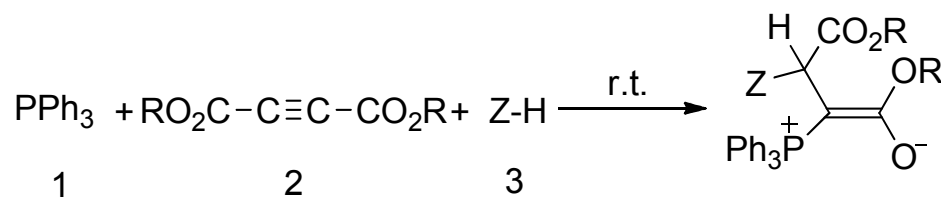

\begin{tabular}{l|ll|llll}
$\mathbf{2}$ & $\mathrm{R}$ & $\mathbf{4}$ & $\mathrm{R}$ & $\%$ Yield & $\mathrm{Z}$ \\
\hline $\mathbf{a}$ & $\mathrm{Me}$ & $\mathbf{a}$ & $\mathrm{Me}$ & 92 & \\
$\mathbf{b}$ & $\mathrm{Et}$ & & & & \\
c & $\mathrm{Bu}^{\mathrm{t}}$ & $\mathbf{b}$ & $\mathrm{Et}$ & 90 & $\mathrm{OMN}$
\end{tabular}

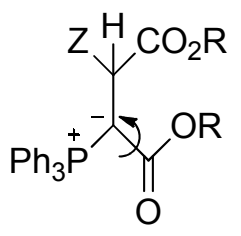

(E)-4 (minor)

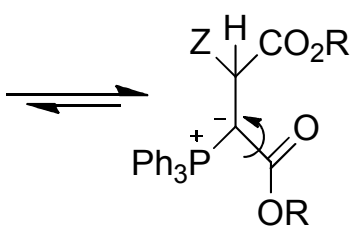

(Z)-4 (major)

Scheme 1. The reaction between triphenylphosphine 1, dialkyl acetylenedicarboxylate $\mathbf{2}$ (2a or 2b) and methyl carbamate 3 for generation of stable phosphorus ylides 4 (4a or $\mathbf{4 b}$ ), and the two $(Z)-\mathbf{4}$ and $(E)-\mathbf{4}$ rotational isomers (major and minor, respectively) of ylide $\mathbf{4 a}$ or $\mathbf{4 b}$.

\section{Computational calculation}

For assignment of the two $E$ - and $Z$-isomers as a minor or major form of phosphorus ylides 4(a,b) containing a methyl carbamato residue, first the $Z$ - and $E$-isomers were optimized for all ylide structures at HF/6-31G(d,p) level of theory ${ }^{15}$ by a Gaussian 98 package program. ${ }^{16}$ The relative stabilization energies for both the geometrical isomers have been calculated at HF/6$31 \mathrm{G}(\mathrm{d}, \mathrm{p})$ and B3LYP/6-311++G(d,p) levels. Atoms in molecules (AIM) and natural population analysis (NPA) methods and also CHelpG keyword at HF/6-31G(d,p) level of theory have been employed in order to gain a better understanding of the most geometrical parameters in both $(E)$ $\mathbf{4}(\mathbf{a}, \mathbf{b})$ and $(Z)-\mathbf{4}(\mathbf{a}, \mathbf{b})$ isomers. The numbers of critical points and intramolecular hydrogen bonds have been recognized as well as the charge of atoms that on the two $Z$ - and $E$-isomers. The 
relative stabilization energies for the two $(Z)-\mathbf{4}(\mathbf{a}, \mathbf{b})$ and $(E)-\mathbf{4}(\mathbf{a}, \mathbf{b})$ geometrical isomers (see Figures 1 and 2) are reported in Table $\mathbf{1}$. As can be seen, the (Z)-4a and the (Z)-4b isomers are more stable than the $(E)-\mathbf{4 a}$ and the $(E)-\mathbf{4 b}$ forms $(6.44$ and $7.61 \mathrm{~kJ} / \mathrm{mol}$, respectively) at B3LYP level.

Table 1. The relative energy $(\mathrm{kJ} / \mathrm{mol})$ for both $Z$ - and $E$-isomers of phosphorus ylide, obtained at $\mathrm{HF} / 6-31 \mathrm{G}(\mathrm{d}, \mathrm{p})$ and of B3LYP/6-311++G(d,p) levels

\begin{tabular}{ccc}
\hline Conformer & HF & B3LYP \\
\hline$(Z)-\mathbf{4 a}$ & 0.00 & 0.00 \\
$(E)-\mathbf{4 a}$ & 6.95 & 6.44 \\
$(Z)-\mathbf{4 b}$ & 0.00 & 0.00 \\
$(E)-\mathbf{4 b}$ & 8.20 & 7.61 \\
\hline
\end{tabular}

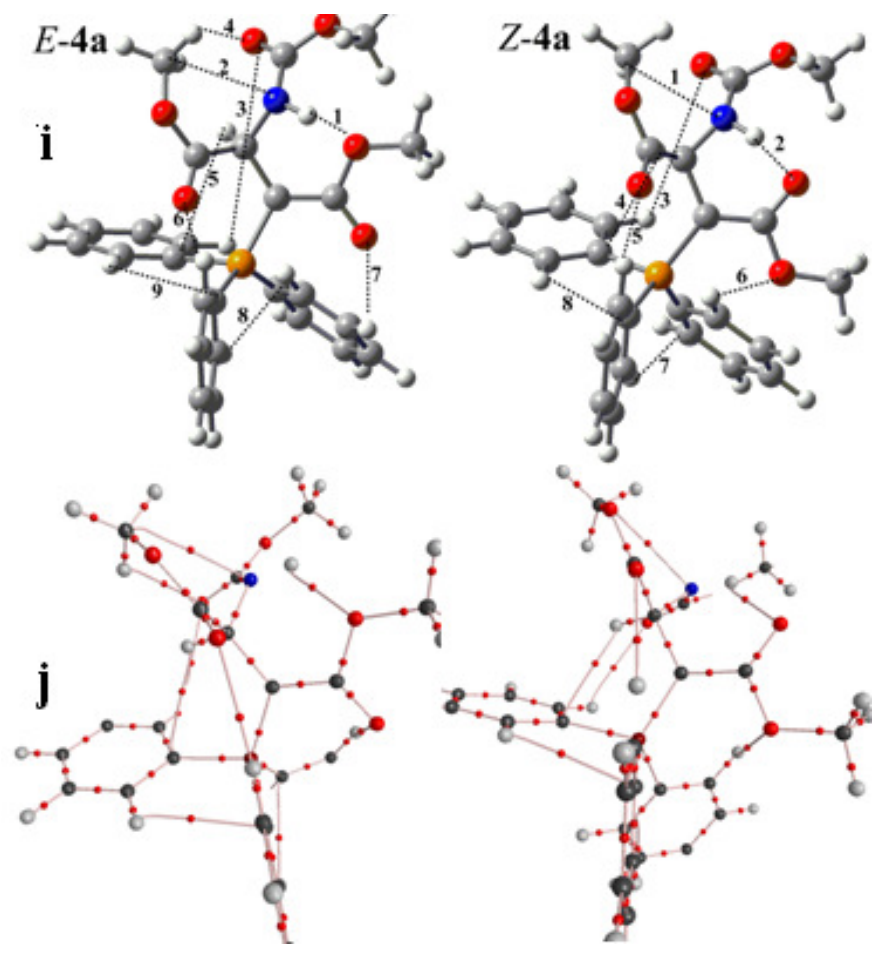

Figure 1. i) Intramolecular hydrogen bonds (dotted lines) in the two $(E)-\mathbf{4 a}$ and $(Z)-\mathbf{4 a}$ geometrical isomers of stable ylide $\mathbf{4 a - j}$ ) A part of molecular graphs, including intermolecular hydrogen bond at critical points (BCPs) for the two $(E)-\mathbf{4 a}$ and $(Z)-\mathbf{4 a}$ geometrical isomers of stable ylide $\mathbf{4 a}$.

Further investigation was undertaken in order to determine more effective factors on stability of the two $Z$ - and $E$-isomers, on the basis of AIM calculations ${ }^{17}$ at HF/6-31G(d,p) level of theory by the AIM2000 program package. ${ }^{27}$ In recent years, AIM theory has often applied in the 
analysis of H-bonds. In this theory, the topological properties of the electron density distribution are derived from the gradient vector field of the electron density $\rho(r)$ and from the Laplacian of the electron density $\nabla^{2} \rho(r)$. The Laplacian of the electron density, $\nabla^{2} \rho(r)$, identifies regions of space wherein the electronic charge is locally depleted $\left[\nabla^{2} \rho(r)>0\right]$ or built up $\left[\nabla^{2} \rho(r)<0\right] .{ }^{24}$

Two interacting atoms in a molecule form a critical point in the electron density, where $\nabla \rho(r)=0$, called the bond critical point (BCP). The values of the charge density and its Laplacian at these critical points give useful information regarding the strength of the H-bonds. ${ }^{18}$ The ranges of $\rho(r)$ and $\nabla^{2} \rho(\mathrm{r})$ are $\left(0.002-0.035 \mathrm{e}^{-\mathrm{a}_{0}}{ }^{3}\right)$ and $\left(0.024-0.139 \mathrm{e} / \mathrm{a}_{0}{ }^{5}\right)$, respectively, if H-bonds exist. ${ }^{19}$ The AIM calculation indicates intramolecular hydrogen bonds and critical points $(\mathrm{H}-$ $\mathrm{BCP}$ ) for the two $(Z) \mathbf{- 4}(\mathbf{a}, \mathbf{b})$ and $(E)-\mathbf{4}(\mathbf{a}, \mathbf{b})$ isomers. Intramolecular H-BCPs with a part of molecular graphs for the two rotational isomers are shown in Figures 1 and 2. The electron density $\rho(r)$, Laplacian of electron density $\nabla^{2} \rho(r)$, and energy density $-\mathrm{H}(r)$ are also reported in Tables 2 and 3. A negative total energy density at the BCP reflects a dominance of potential energy density, which is the consequence of accumulated stabilizing electronic charge. ${ }^{20}$

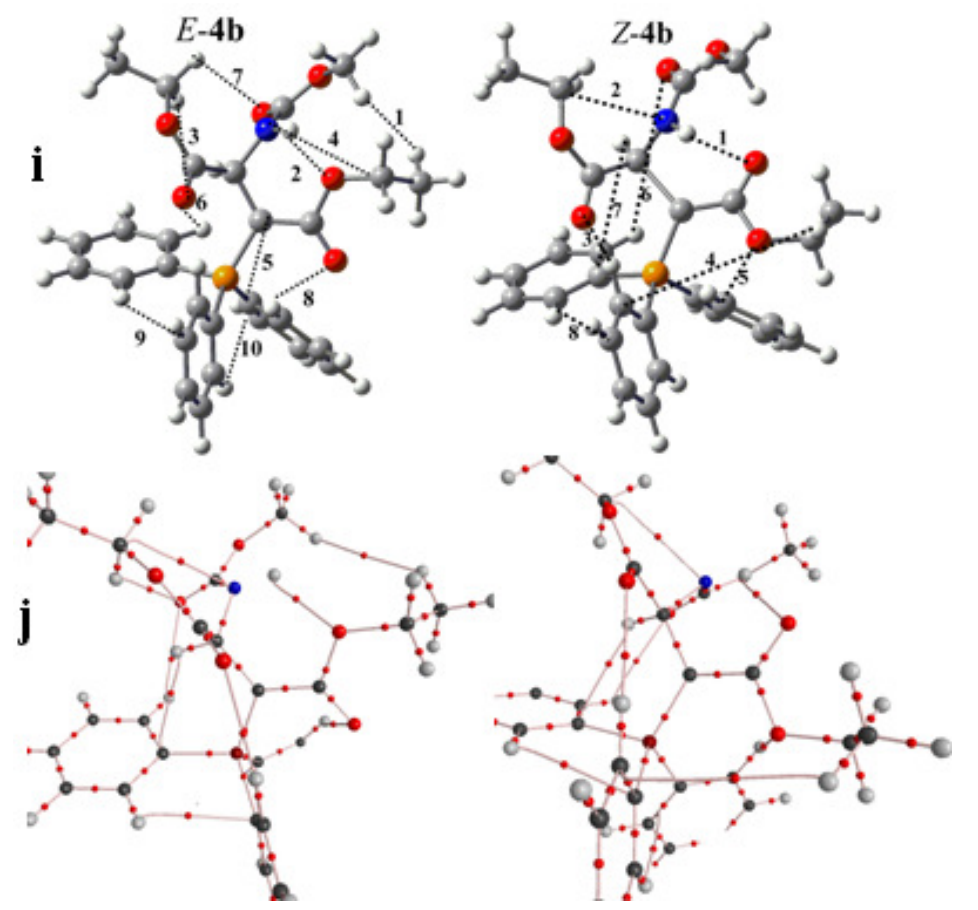

Figure 2. i) Intramolecular hydrogen bonds (dotted lines) in the two $(E)-\mathbf{4 b}$ and $(Z)-\mathbf{4 b}$ geometrical isomers of stable ylide $\mathbf{4 b}$. j) A part of molecular graphs, including intermolecular hydrogen bond at critical points (BCPs) for the two $(E)-\mathbf{4 b}$ and $(Z)-\mathbf{4 b}$ geometrical isomers of stable ylide $\mathbf{4 b}$. 
Table 2. The values of $\mathrm{a}=\rho(r) \times 10^{3}, \mathrm{~b}=\nabla^{2} \rho(r) \times 10^{3}$ and $\mathrm{c}=-\mathrm{H}(r) \times 10^{4}$ for both $(Z)-\mathbf{4 a}$ and $(E)-\mathbf{4 a}$ isomers of ylide $\mathbf{4 a}$ calculated at the hydrogen bond critical points. All quantities are in atomic units

\begin{tabular}{cccccccc}
\hline$E$ & $\mathrm{a}$ & $\mathrm{b}$ & $\mathrm{c}$ & $Z$ & $\mathrm{a}$ & $\mathrm{b}$ & $\mathrm{c}$ \\
\hline 1 & 19.48 & 70.88 & 1.15 & 1 & 12.19 & 49.31 & 14.79 \\
2 & 11.78 & 47.94 & 14.48 & 2 & 4.99 & 21.18 & 10.52 \\
3 & 5.94 & 24.68 & 10.18 & 3 & 10.91 & 39.17 & 17.06 \\
4 & 7.00 & 28.40 & 11.52 & 4 & 11.92 & 40.44 & 3.20 \\
5 & 11.28 & 40.11 & 16.70 & 5 & 8.73 & 34.93 & 11.41 \\
6 & 10.37 & 36.07 & 4.79 & 6 & 9.33 & 32.04 & 14.60 \\
7 & 13.22 & 46.42 & 5.48 & 7 & 9.59 & 37.04 & 18.09 \\
8 & 8.99 & 32.94 & 16.01 & & & & \\
9 & 10.16 & 39.15 & 18.66 & & & & \\
\hline
\end{tabular}

Table 3. The values of $\mathrm{a}=\rho(r) \times 10^{3}, \mathrm{~b}=\nabla^{2} \rho(r) \times 10^{3}$ and $\mathrm{c}=-\mathrm{H}(r) \times 10^{4}$ for both $(Z)-\mathbf{4 c}$ and $(E)-\mathbf{4 c}$ isomers of ylide $\mathbf{4 c}$ calculated at the hydrogen bond critical points. All quantities are in atomic units

\begin{tabular}{cccccccc}
\hline $\mathrm{E}$ & $\mathrm{a}$ & $\mathrm{b}$ & $\mathrm{c}$ & $\mathrm{Z}$ & $\mathrm{a}$ & $\mathrm{b}$ & $\mathrm{c}$ \\
\hline 1 & 1.62 & 5.40 & 3.60 & 1 & 11.87 & 48.99 & 15.65 \\
2 & 19.06 & 69.40 & 1.32 & 2 & 11.98 & 40.54 & 3.05 \\
3 & 6.13 & 25.15 & 10.04 & 3 & 2.03 & 6.56 & 3.84 \\
4 & 11.46 & 47.63 & 15.20 & 4 & 8.90 & 35.55 & 11.46 \\
5 & 11.26 & 40.08 & 16.68 & 5 & 5.42 & 22.76 & 10.78 \\
6 & 10.47 & 36.32 & 4.67 & 6 & 10.95 & 39.27 & 17.02 \\
7 & 7.14 & 28.91 & 11.60 & 7 & 9.67 & 36.73 & 17.71 \\
8 & 12.97 & 45.77 & 5.86 & 8 & 9.36 & 32.15 & 14.66 \\
9 & 10.20 & 39.17 & 18.61 & & & & \\
10 & 8.98 & 32.81 & 15.93 & & & & \\
\hline
\end{tabular}

Herein, the number of hydrogen bonds in both categories $((E)-\mathbf{4 a}$ and $(Z)-\mathbf{4 a})$ and $((E)-\mathbf{4 b}$ and $(Z)-\mathbf{4 b})$ is 9 and 7 and also 10 and 8, respectively. The values of $\rho(r)$ and $\nabla^{2} \rho(r)$ are in the ranges $\left(0.006-0.012\right.$ and $\left.0.005-0.012 \mathrm{e}^{\mathrm{a}} \mathrm{a}_{0}{ }^{3}\right),\left(0.002-0.019\right.$ and $\left.0.002-0.011 \mathrm{e} / \mathrm{a}_{0}{ }^{3}\right),(0.025-0.070$ and $\left.0.021-0.049 \mathrm{e} / \mathrm{a}_{0}{ }^{5}\right)$ and $\left(0.005-0.069\right.$ and $\left.0.007-0.049 \mathrm{e} / \mathrm{a}_{0}{ }^{5}\right)$, respectively. In addition, the Hamiltonian $-\mathrm{H}(r)$ is in the range (1.15-18.7 and 3.20-18.1 au) and (1.32-18.6 and 3.05-17.7 au) (Tables 2 and 3). These HBs show $\nabla^{2} \rho(r)>0$ and $\mathrm{H}(r)<0$, which according to classification of Rozas et $a{ }^{21}{ }^{21}$ are medium-strength hydrogen bonds. In both ylides the dipole moments for the two $(E)-\mathbf{4 a}$ and $(E)-\mathbf{4 b}$ isomers (2.10 and $1.96 \mathrm{D}$, respectively) are smaller than those for the two $(Z)-4 a$ and $(Z)-4 b$ isomers (4.96 and $4.72 \mathrm{D}$, respectively) and the values of $-\mathrm{H}_{\text {tot }}\left(=\sum \mathrm{H}(r)\right.$ ) for the two $(E)-\mathbf{4 a}$ and $(E)-\mathbf{4 b}$ isomers (103.5 and 98.97 au, respectively) are larger than those for the 
two (Z)-4a and (Z)-4b isomers (89.67 and 94.17au, respectively). These differences in the most important geometrical parameters of the $(E)-\mathbf{4}(\mathbf{a}, \mathbf{b})$ and $(Z)-\mathbf{4}(\mathbf{a}, \mathbf{c})$, accompanied with a fairly difference in dipole moment and difference in $-\mathrm{H}(r)$ altogether make a slight stability on these isomers in comparison with the $(Z)-\mathbf{4}(\mathbf{a}, \mathbf{b})$ forms (Table 4). On the contrary, according to the theoretical calculations (Table 1), both the $(Z)-\mathbf{4 a}$ and $(Z)-\mathbf{4 b}$ have a slight stability with respect to the two $(E)-\mathbf{4 a}$ and $(E)-\mathbf{4 b}(6.95$ and $8.20 \mathrm{~kJ} / \mathrm{mol})$ isomers The results that are shown in Table $\mathbf{1}$, involving the relative energy can be taken as a dominate factor of stability on the two $(Z)-\mathbf{4 a}$ and $(Z)-\mathbf{4 b}$, which are compatible with the experimental results from the ${ }^{1} \mathrm{H},{ }^{13} \mathrm{C}$ and ${ }^{31} \mathrm{P}$ NMR spectroscopy.

Table 4. The most important geometrical parameters involving the value of $-\mathrm{H}_{\mathrm{tot}} / \mathrm{au}$, dipole moment/D and number of hydrogen bonds for the two $Z$ - and $E$-isomers of ylides $\mathbf{4 a}$ and $\mathbf{4 c}$

\begin{tabular}{cccc}
\hline Isomer & $-\mathrm{H}_{\text {tot }} / \mathrm{au}$ & Dipole moment $/ \mathrm{D}$ & $\begin{array}{c}\text { Number of } \\
\text { hydrogen bonds }\end{array}$ \\
\hline$(Z)-\mathbf{4 a}$ & 89.67 & 4.96 & 7 \\
$(E)-\mathbf{4 a}$ & 98.97 & 2.10 & 9 \\
$(Z)-\mathbf{4 b}$ & 94.17 & 4.72 & 8 \\
$(E)-\mathbf{4 b}$ & 103.5 & 1.96 & 10 \\
\hline
\end{tabular}

Also, the charges on different atoms which are calculated by AIM and NPA methods and also CHelpG keyword at HF/6-31G(d,p) level are reported in Table 5 for the two Z- and Eisomers of ylides $\mathbf{4 a}$ and $\mathbf{4 b}$. There is a good agreement between the results obtained from the two methods and employment of CHelpG keyword. Furthermore, the individual chemical shifts have been characterized by NMR calculations at mentioned level for only the two major and minor of $(Z)-4 a$ and $(E)-4 a$ geometrical isomers. The total spin-spin coupling constant is the sum of four components: the paramagnetic spin-orbit (PSO), diamagnetic spin-orbit (DSO), Fermi-contact $(\mathrm{FC})$, and spin-dipole (SD) terms. The value of chemical shifts $(\delta)$ and coupling constants $\left(J_{\mathrm{x}-\mathrm{y}}\right)$ is reported in Tables 6-9. As can be seen there is good agreement between both the experimental and theoretical chemical shifts $(\delta)$ and coupling constants $\left(\mathrm{J}_{\mathrm{x}-\mathrm{y}}\right)$.

Table 5. The charges on different atoms for the two $Z$ - and $E$-isomers in both ylides $\mathbf{4 a}$ and $\mathbf{4 b}$ at $\mathrm{HF} / 6-31 \mathrm{G}(\mathrm{d}, \mathrm{p})$ level

\begin{tabular}{ccccc}
\hline $\begin{array}{c}\text { Number of } \\
\text { atom }\end{array}$ & $(Z)-\mathbf{4 a}$ & $(E)-\mathbf{4 a}$ & $(Z)-\mathbf{4 b}$ & $(E)-\mathbf{4 b}$ \\
\hline $\mathrm{C} 1$ & $0.74^{\mathrm{a}}(0.73)^{\mathrm{b}}$ & $0.73(0.66)$ & $0.74(0.57)$ & $0.74(0.73)$ \\
& $(-0.14)^{\mathrm{c}}$ & $(-0.14)$ & $(-0.14)$ & $(-0.14)$ \\
$\mathrm{C} 2$ & $-0.80(-0.99)$ & $-0.80(-0.95)$ & $-0.80(-0.80)$ & $-0.79(-0.81)$ \\
& $(-0.84)$ & $(-0.83)$ & $(-0.84)$ & $(0.83)$ \\
\hline
\end{tabular}


Table 5. Continue

\begin{tabular}{ccccc}
\hline $\begin{array}{c}\text { Number of } \\
\text { atom }\end{array}$ & $(\mathrm{Z}) \mathbf{- 4 a}$ & $(\mathrm{E}) \mathbf{- 4 a}$ & $(\mathrm{Z}) \mathbf{- 4 b}$ & $(\mathrm{E}) \mathbf{- 4 b}$ \\
\hline \multirow{2}{*}{ C4 } & $1.84(1.04)$ & $1.84(0.94)$ & $1.85(0.97)$ & $1.83(0.95)$ \\
& $(0.91)$ & $(0.90)$ & $(0.91)$ & $(0.90)$ \\
O5 & $-1.41(-0.70)$ & $-1.40(-0.72)$ & $-1.41(-0.67)$ & $-1.43(0.70)$ \\
& $(-0.79)$ & $(-0.78)$ & $(-0.80)$ & $(-0.77)$ \\
O6 & $-1.29(-0.47)$ & $-1.29(-0.31)$ & $-1.29(-0.52)$ & $-1.28(-0.45)$ \\
& $(-0.65)$ & $(-0.67)$ & $(-0.67)$ & $(-0.68)$ \\
P3 & $3.25(0.38)$ & $3.25(0.41)$ & $3.25(0.21)$ & $3.24(0.25)$ \\
& $(1.75)$ & $(1.75)$ & $(1.75)$ & $(1.75)$ \\
\hline
\end{tabular}

${ }^{\mathrm{a} C}$ Calculated by AIM method. ${ }^{\mathrm{b}}$ Calculated by $\mathrm{CHelpG}$ keyword. ${ }^{\mathrm{C}}$ Calculated by NPA method.

Table 6. Selected ${ }^{13} \mathrm{C}$ NMR chemical shifts ( $\delta$ in ppm) and coupling constants $(J$ in $\mathrm{Hz})$ for some functional groups in $(E)-\mathbf{4 a}$ isomer as a minor form

\begin{tabular}{ccc}
\hline groups & $\delta^{\mathrm{C}} / \mathrm{ppm}$ & $J_{\mathrm{PC}} / \mathrm{Hz}$ \\
\hline $3 \mathrm{~s}, 3 \mathrm{OMe}$ & $59.92^{\mathrm{a}}(49.71)^{\mathrm{b}}$ & \\
& $52.69(50.14)$ & \\
$\mathrm{d}, \mathrm{C}_{\text {ipso }}$ & $125.97(126.01)$ & $92.6^{\mathrm{a}}(91.57)^{\mathrm{b}}$ \\
$\mathrm{d}, \mathrm{C}_{\text {ortho }}$ & $133.65(133.50)$ & \\
$\mathrm{d}, \mathrm{C}_{\text {meta }}$ & $128.6(126.8)$ & \\
$\mathrm{d}, \mathrm{C}_{\text {para }}$ & $131.96(132.60)$ & \\
$\mathrm{d}, \mathrm{C}^{7}=\mathrm{O}$ & $156.40(157.54)$ & \\
\hline
\end{tabular}

${ }^{\mathrm{a}}$ Experimental data in accord with the results reported in the literature.

${ }^{\mathrm{b}}$ Theoretical data.

Table 7. Selected ${ }^{1} \mathrm{H}$ NMR chemical shifts ( $\delta$ in ppm) and coupling constants $(J$ in $\mathrm{Hz}$ ) for some functional groups In the $(E)-\mathbf{4 a}$ isomer as a minor form

\begin{tabular}{ccc}
\hline groups & $\delta^{\mathrm{H}} / \mathrm{ppm}$ & $J_{\mathrm{PH}} / \mathrm{Hz}$ \\
\hline $9 \mathrm{H}, 3 \mathrm{~s}, 3 \mathrm{OCH}_{3}$ & $3.56^{a}(3.58)^{\mathrm{b}}$ & \\
& $3.63(3.59)$ & \\
$1 \mathrm{H}, \mathrm{d}, \mathrm{P}=\mathrm{C}-\mathrm{C}-\mathrm{H}$ & $3.68(3.69)$ & $8.8^{\mathrm{a}}(8.5)^{\mathrm{b}}$ \\
\hline
\end{tabular}

${ }^{a}$ Experimental data in accord with the results reported in the literature. ${ }^{\mathrm{b}}$ Theoretical data. 
Table 8. Selected ${ }^{1} \mathrm{H}$ NMR chemical shifts ( $\delta$ in ppm) for some functional groups in the (Z)-4a isomer as a major form

\begin{tabular}{ccc}
\hline groups & $\delta^{\mathrm{H}} / \mathrm{ppm}$ & $J_{\mathrm{PH}} / \mathrm{Hz}$ \\
\hline & $3.15^{\mathrm{a}}(3.14)^{\mathrm{b}}$ & \\
$9 \mathrm{H}, 3 \mathrm{~s}, 3 \mathrm{OCH}_{3}$ & $3.61(3.58)$ & \\
& $3.72(3.71)$ & $9.2^{\mathrm{a}}(8.5)^{\mathrm{b}}$ \\
\hline
\end{tabular}

${ }^{\mathrm{a}}$ Experimental data in accord with the results reported in the literature. ${ }^{\mathrm{b}}$ Theoretical data.

Table 9. Selected ${ }^{13} \mathrm{C}$ NMR chemical shifts ( $\delta$ in ppm) and coupling constants $(J$ in Hz) for some functional groups in $(Z)-\mathbf{4 a}$ isomer as a major form

\begin{tabular}{ccc}
\hline groups & $\delta^{\mathrm{C}} / \mathrm{ppm}$ & $J_{\mathrm{PC}} / \mathrm{Hz}$ \\
\hline & $48.84^{\mathrm{a}}(48.60)^{\mathrm{b}}$ & \\
3s, 3OMe & $51.69(51.52)$ & \\
& $52.11(51.98)$ & $92.3^{\mathrm{a}}(91.0)^{\mathrm{b}}$ \\
$\mathrm{d}, \mathrm{C}_{\text {ipso }}$ & $126.58(127.45)$ & \\
d, $\mathrm{C}_{\text {ortho }}$ & $133.65(133.09)$ & \\
d, $\mathrm{C}_{\text {meta }}$ & $128.50(125.54)$ & \\
d, $\mathrm{C}_{\text {para }}$ & $131.96(132.01)$ & \\
d, C $\mathrm{C}^{45}=\mathrm{O}$ & $173.76(172.99)$ & $12.5(12.4)$ \\
$\mathrm{d}, \mathrm{P}=\mathrm{C}-\mathrm{CH}$ & $52.20(53.66)$ & \\
\hline
\end{tabular}

${ }^{\mathrm{a}}$ Experimental data in accord with the results reported in the literature. ${ }^{\mathrm{b}}$ Theoretical data.

\section{Kinetic studies}

To gain further insight into the reaction mechanism between triphenylphosphine 1, dialkyl acetylenedicarboxylates $\mathbf{2}$ and methyl carbamate $\mathbf{3}$ (as a $\mathrm{NH}$-acid) for generation of phosphorus ylids $4 \mathbf{a}-\mathbf{c}$, a kinetic study of the reactions was undertaken by UV spectrophotometry. To find the appropriate wavelength to follow the progress of the reaction, in the first experiment, $3 \times 10^{-3} \mathrm{M}$ solution of compounds were prepared in 1,2-dichloroethane as solvent and the relevant spectra were recorded over the wavelength range 190-400 nm. Figures 3, 4 and 5 show the ultraviolet spectra of compounds $\mathbf{1}, \mathbf{2 c}$ and 3 respectively. In a second experiment, a $1 \mathrm{ml}$ aliquot from the $3 \times 10^{-3} \mathrm{M}$ solutions of each compound of $\mathbf{1}$ and $\mathbf{3}$ was pipetted first into a quartz spectrophotometer cell (as there is no reaction between them), later, a $1 \mathrm{ml}$ aliquot of the $3 \times 10^{-3} \mathrm{M}$ solution of reactant $\mathbf{2 c}$ was added to the mixture and the reaction monitored by recording scans of the entire spectra every 8 min over the whole reaction time at ambient temperature. The ultraviolet spectra shown in Figure 6 are typical. From this, the appropriate wavelength was found to be $303 \mathrm{~nm}$ (corresponding mainly to triphenylphosphine 1). At this wavelength, compounds $\mathbf{1}, \mathbf{2}$ and $\mathbf{3}$ have little absorbance. This then provided the opportunity to fully investigate the kinetics 
of the reaction between triphenylphosphine (1), di-tert-butyl acetylenedicarboxylate (2c) and methyl carbamate $(\mathbf{3})$ at $303 \mathrm{~nm}$ in the presence of 1,2-dichloroethane as solvent. Since the spectrophotometer cell of the UV instrument had a 10-mm light-path cuvette, the UV-vis spectra of compound $4 \mathbf{c}$ were measured over the concentration range $\left(2 \times 10^{-4} \mathrm{M} \leq \mathrm{M}_{4 \mathrm{c}} \leq 10^{-3} \mathrm{M}\right)$ to check for a linear relationship between absorbance values and concentrations. With the suitable concentration range and wavelength identified, the following procedure was employed.

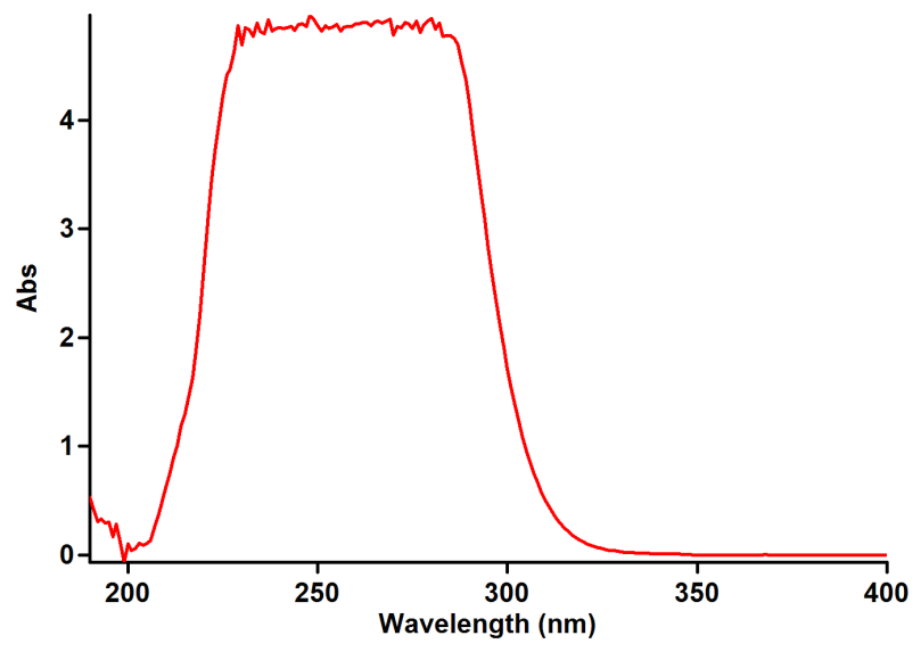

Figure 3. UV spectrum of $10^{-3} \mathrm{M}$ triphenylphosphine (1) in 1,2-dichloroethane.

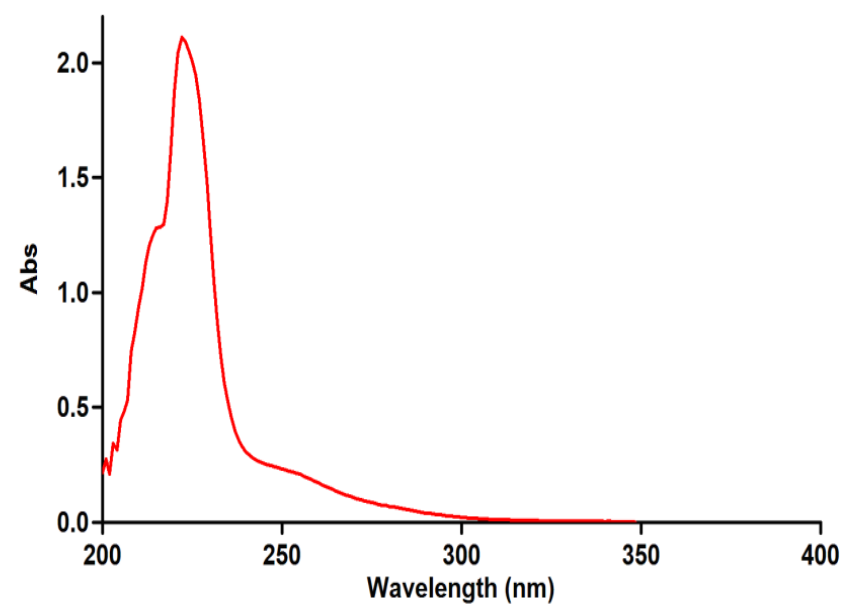

Figure 4. UV spectrum of $10^{-3} \mathrm{M}$ di-tert-butyl acetylenedicarboxylate (2c) in 1,2-dichloroethane. 


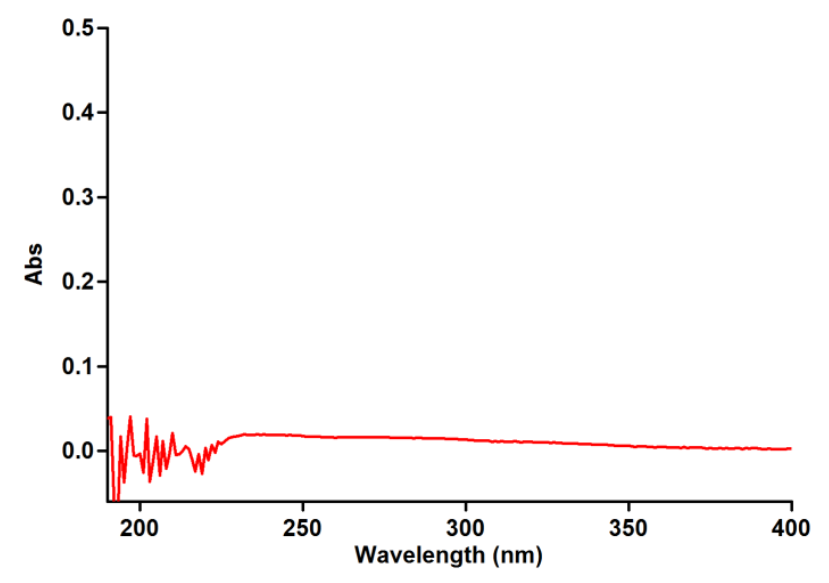

Figure 5. UV spectrum of $10^{-3} \mathrm{M}$ methyl carbamate 3 in 1,2-dichloroethane.

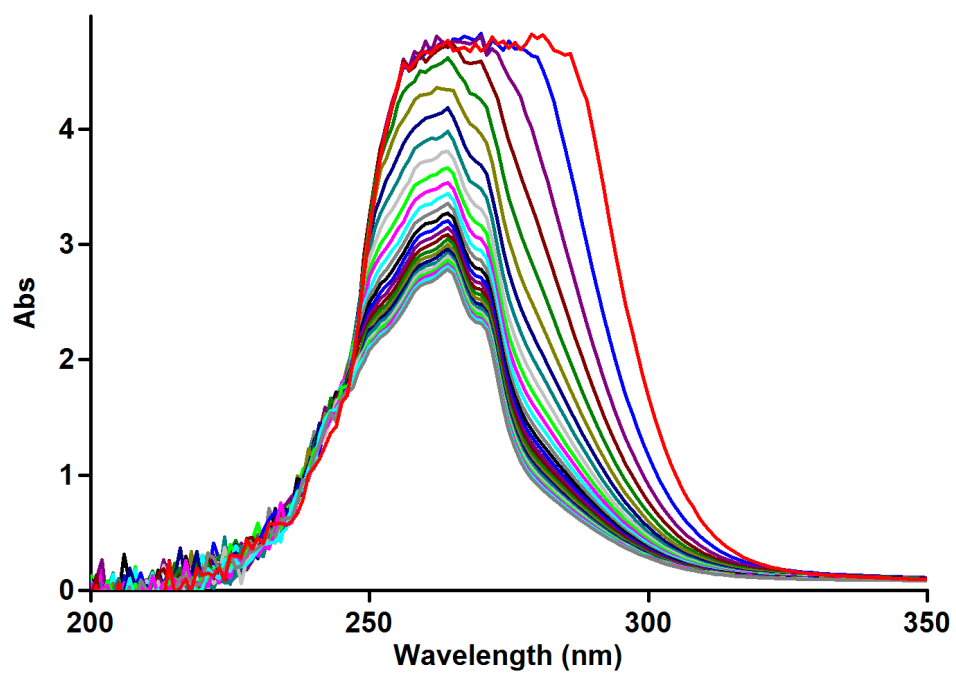

Figure 6. UV spectra of the reaction between 1, 2c and 3 with $10^{-3} \mathrm{M}$ concentration of each compound as reaction proceeds in 1,2-dichloroethane with $10 \mathrm{~mm}$ light-path cell.

For each kinetic experiment, first a $1 \mathrm{ml}$ aliquot from each freshly made $3 \times 10^{-3} \mathrm{M}$ solution of compounds $\mathbf{1}$ and $\mathbf{3}$ in 1,2-dichloroethane was pipetted into a quartz cell, and then a $1 \mathrm{ml}$ aliquot of the $3 \times 10^{-3} \mathrm{M}$ of solution of reactant $2 \mathrm{c}$ was added to the mixture, keeping the temperature at $12.0^{\circ} \mathrm{C}$. The reaction kinetics was followed by plotting UV absorbance against time. Figure 7 shows the absorbance change (dotted line) versus time for the 1:1:1 addition reaction between

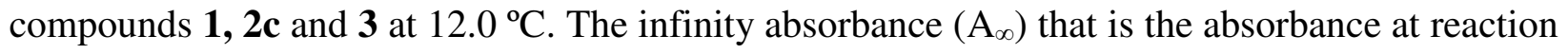
completion, can be obtained from Figure 7 at $\mathrm{t}=232 \mathrm{~min}$. With respect to this value, zero, first or second curve fitting could be drawn automatically for the reaction by the software ${ }^{22}$ associated with the UV instrument. Using the original experimental absorbance versus time data provided a 
second-order fit curve (solid line) with standard deviation of 0.0033 , which provides the most satisfactory agreement with the experimental curve (dotted line) as shown in Figure 7 . Thus, the reaction between triphenylphosphine $\mathbf{1}$, di-tert-butyl acetylenedicarboxylate $\mathbf{2 c}$ and $\mathbf{3}$ follows second-order kinetics. The second-order rate constant $\left(k_{2}\right)$ is then calculated which reported in Table 10.

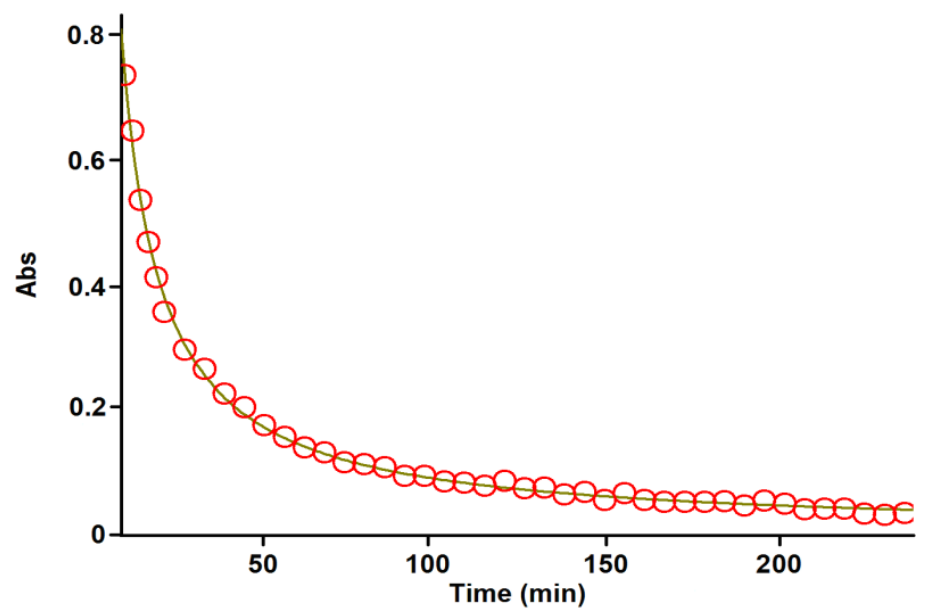

Figure 7. Second order fit curve (full line) accompanied by the original experimental curve (dotted line) for the reaction between compounds $\mathbf{1 ,} \mathbf{2 c}$ and $\mathbf{3}$ at $303 \mathrm{~nm}$ and $12.0^{\circ} \mathrm{C}$ in $1,2-$ dichloroethane.

Furthermore, kinetic studies were carried out using the same concentration of each reactant in the continuation of experiments with concentrations of $5 \times 10^{-3} \mathrm{M}$ and $7 \times 10^{-3} \mathrm{M}$. As expected, the second-order rate constant was independent of concentration and its value was the same as in the previous experiment. In addition, the overall order of reaction was also 2.

\section{Effect of solvents and temperature}

To determine the effect of change in temperature and solvent environment on the rate of reaction, it was elected to perform various experiments at different temperatures and solvent polarities but otherwise under the same conditions as for the previous experiment. For this purpose, ethyl acetate with dielectric constant of six was chosen as a suitable solvent since it is not only could dissolve all compounds but also did not react with them. The effects of solvents and temperature on the rate constant are given in Table 10. The results show that the rate of reaction in each case was increased at higher temperature. In addition, the rate of reaction between $\mathbf{1}, \mathbf{2 c}$ and $\mathbf{3}$ was accelerated in a higher dielectric constant environment (1,2-dichloroethane) in comparison with a lower dielectric constant environment (ethyl acetate) at all temperatures investigated. In the temperature range studied, the dependence of the second-order rate constant $\left(\ln k_{2}\right)$ of the reactions on reciprocal temperature is consistent with the Arrhenius equation, giving activation energy of the reaction between $\mathbf{1}, \mathbf{2 c}$ and $\mathbf{3}$. 
Table 10. Values of overall second order rate constant for all reactions $(\mathbf{1}, \mathbf{2 c}$ and $\mathbf{3}),(\mathbf{1}, \mathbf{2 b}$ and 3) and (1, 2a and $\mathbf{3})$ in the presence of solvents such as 1,2-dichloroethane and ethyl acetate, respectively, at all temperatures investigated

\begin{tabular}{cccccc}
\hline \multirow{2}{*}{ Reaction } & Solvent & \multicolumn{4}{c}{$k_{2} \cdot \mathrm{M}^{-1} \cdot \mathrm{min}^{-1}$} \\
\cline { 2 - 5 } 1, 2c and 3 & 1,2-dichloroethane & $59.6 \pm 2.3$ & $86.3 \pm 2.5$ & $112.5 \pm 2.6$ & $144.4 \pm 4.7$ \\
& ethyl acetate & $51.1 \pm 1.9$ & $79.5 \pm 2.2$ & $102.2 \pm 2.2$ & $129.8 \pm 3.1$ \\
\hline \multirow{2}{*}{$\mathbf{1 , 2 b}$ and $\mathbf{3}$} & 1,2-dichloroethane & $242.3 \pm 3.9$ & $276.0 \pm 3.8$ & $302.4 \pm 4.0$ & $347.2 \pm 6.1$ \\
& ethyl acetate & $158.0 \pm 2.8$ & $195.1 \pm 3.0$ & $228.5 \pm 3.2$ & $256.6 \pm 5.0$ \\
\hline \multirow{2}{*}{$\mathbf{1 , 2 a}$ and 3 } & 1,2-dichloroethane & $341.0 \pm 5.0$ & $371.1 \pm 5.1$ & $413.2 \pm 5.5$ & $458.3 \pm 7.2$ \\
& ethyl acetate & $317.1 \pm 4.4$ & $356.3 \pm 4.8$ & $402.9 \pm 5.0$ & $436.6 \pm 6.7$ \\
\hline
\end{tabular}

Effect of concentration: To determine the reaction order with respect to triphenylphosphine $\mathbf{1}$ and dialkyl acetylene-dicarboxylate $\mathbf{2}(\mathbf{2 c})$, in the continuation of experiments, all kinetic studies were carried out in the presence of excess $\mathbf{3}$. Under these conditions, the rate equation may therefore be expressed as:

$$
\text { rate }=k_{o b s}[1]^{\alpha}[2]^{\beta} k_{o b s}=k_{2}[3]^{\gamma} \quad \text { or } \ln k_{o b s}=\ln k_{2}+\gamma \ln [3]
$$

In this case $\left(3 \times 10^{-2} \mathrm{M}\right.$ of 3 instead of $\left.3 \times 10^{-3} \mathrm{M}\right)$ using the original experimental absorbance versus time data provides a second order fit curve (full line) against time at $303 \mathrm{~nm}$ which exactly fits the experimental curve. The value of rate constant was the same as that of obtained from the previous experiment $\left(3 \times 10^{-3} \mathrm{M}\right)$. Repetition of the experiments with $5 \times 10^{-2} \mathrm{M}$ and $7 \times 10^{-}$ ${ }^{2} \mathrm{M}$ of 3 gave, separately, the same fit curve and rate constant. In fact, the experimental data indicated that the observed pseudo second order rate constant $\left(k_{\mathrm{obs}}\right)$ was equal to the second order rate constant $\left(k_{2}\right)$, this is possible when $\gamma$ is zero in equation 1 . It is appears, therefore, that the reaction is zero and second order with respect to $\mathbf{3}$ (NH-acid) and the sum of $\mathbf{1}$ and $\mathbf{2}(\mathbf{2 c})(\alpha+\beta$ $=2$ ), respectively.

To determine the reaction order with respect to triphenylphosphine $\mathbf{1}$, the continuation of experiment was performed in the presence of excess of $2(\mathbf{2 c})$ (rate $=k_{\text {obs }}^{\prime}[1]^{\alpha}[3]^{\gamma}, k^{\prime}{ }_{\text {obs }}=k_{2}$ $\left.[2]^{\beta}(2)\right)$. The original experimental absorbance versus time data and provides a pseudo first order fit curve at $303 \mathrm{~nm}$, which exactly fits the experimental curve (dotted line).

As a result since $\gamma=0$ (as determined previously), it is reasonable to accept that the reaction is first order with respect to compound $\mathbf{1}(\alpha=1)$. Because the overall order of reaction is $2(\alpha+\beta$ 
$+\gamma=2)$ it is obvious that $\beta=1$ and order of dialkyl acetylenedicarboxylate $\mathbf{2}(\mathbf{2 c})$ must be equal to one. This observation was obtained also for reactions between $(\mathbf{1}, \mathbf{2 b}$ and $\mathbf{3})$ and $(\mathbf{1}, \mathbf{2 a}$ and $\mathbf{3})$. Based on the above results, a simplified proposed reaction mechanism is shown in Scheme 2.

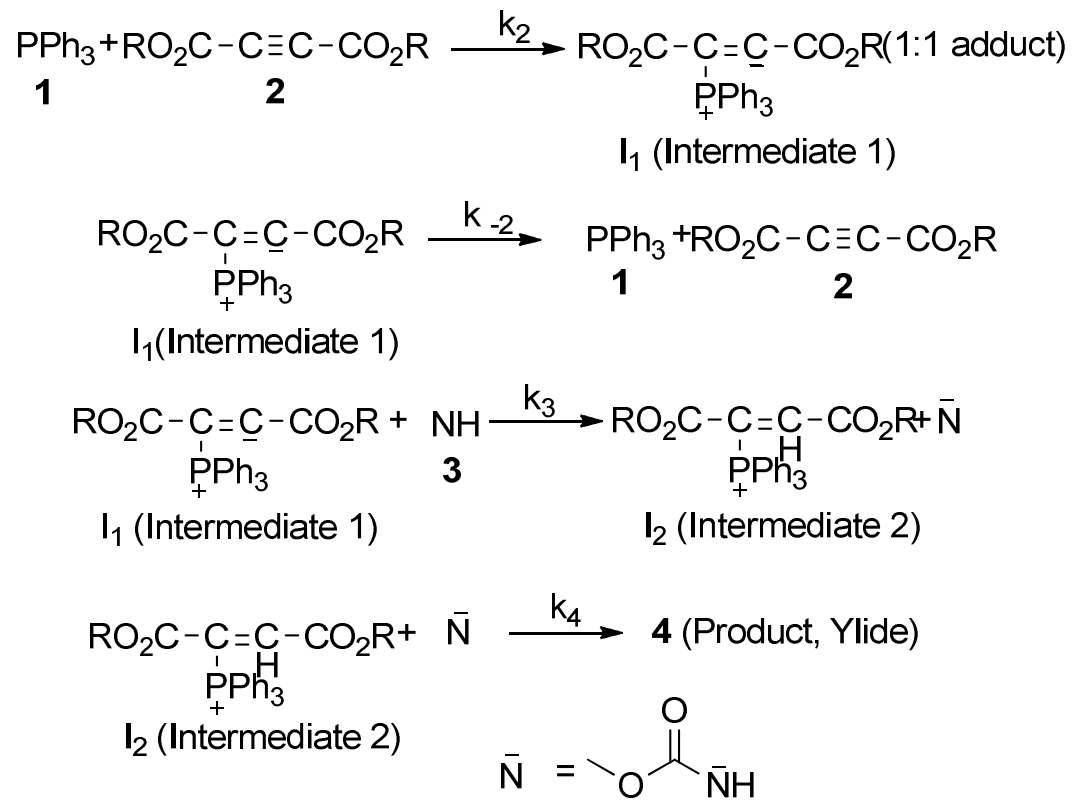

Scheme 2. Proposed mechanism for the reaction between $\mathbf{1 ,} \mathbf{2}(\mathbf{2 a}, \mathbf{2 b}$ or $\mathbf{2 c})$ and $\mathbf{3}$ for generation of phosphorus ylides $\mathbf{4 a - c .}$

Two steps involving 3 and 4 are not determining setep, although all evidences are compatible with the first step $\left(k_{2}\right)$ of the proposed mechanism and would allow it to be the rate-determining step. However, a good kinetic description of the experimental result using a mechanistic scheme based upon the steady state approximation is frequently taken as evidence of its validity. By application of this, the rate formation of product $\mathbf{4}$ from the reaction mechanism (Scheme 2) is given by:

$$
\frac{d[4]}{d t}=\frac{d[\text { ylide }]}{d t}=\text { rate }=k_{4}\left[I_{2}\right]\left[N^{-}\right]
$$

We can apply the steady-state approximation to $\left[I_{1}\right]$ and $\left[I_{2}\right]$;

$$
\begin{gathered}
\frac{d\left[I_{1}\right]}{d t}=k_{2}[1][2]-k_{-2}\left[I_{1}\right]-k_{3}\left[I_{1}\right][3], \\
\frac{d\left[I_{2}\right]}{d t}=k_{3}\left[I_{1}\right][3]-k_{4}\left[I_{2}\right]\left[N^{-}\right]
\end{gathered}
$$

To obtain a suitable expression for $\left[I_{2}\right]$ to put into equation (2) we can assume that, after an initial brief period, the concentration of $\left[I_{1}\right]$ and $\left[I_{2}\right]$ achieves a steady state with their rates of formation and rates of disappearance just balanced. Therefore $\frac{d\left[I_{1}\right]}{d t}$ and $\frac{d\left[I_{2}\right]}{d t}$ are zero and we can obtain expressions for $\left[I_{2}\right]$ and $\left[I_{1}\right]$ as follows: 


$$
\begin{array}{ll}
\frac{d\left[I_{2}\right]}{d t}=0 & ,\left[I_{2}\right]=\frac{k_{3}\left[I_{1}\right][3]}{k_{4}\left[N^{-}\right]} \\
\frac{d\left[I_{1}\right]}{d t}=0, & {\left[I_{1}\right]=\frac{k_{2}[1][2]}{k_{-2}+k_{3}[3]}}
\end{array}
$$

We can now replace $\left[I_{1}\right]$ in the equation (3) to obtain this equation:

$$
\left[I_{2}\right]=\frac{k_{2} k_{3}[1][2][3]}{k_{4}\left[N^{-}\right]\left[k_{-2}+k_{3}[3]\right]}
$$

The value of $\left[I_{2}\right]$ can be put into equation (2) to obtain the rate equation (5) for proposed

mechanism: $\quad$ rate $=\frac{k_{2} k_{3} k_{4}[1][2][3]\left[N^{-}\right]}{k_{4}\left[N^{-}\right]\left[k_{-2}+k_{3}[3]\right]} \quad$ or $\quad$ rate $=\frac{k_{2} k_{3}[1][2][3]}{\left[k_{-2}+k_{3}[3]\right]}$

Since experimental data indicated that steps $3\left(k_{3}\right)$ and $4\left(k_{4}\right)$ are fast but step $1\left(k_{2}\right)$ is slow, it is therefore reasonable to make the following assumption: $k_{3}[3]>>\boldsymbol{k}_{\mathbf{- 2}}$

So the rate equation becomes: $\quad$ rate $=k_{2}[1][2]$

This equation which was obtained from a mechanistic scheme (Scheme 2) by applying the steady-state approximation is compatible with the results obtained by UV spectrophotometry. With respect to the equation (6) that shows the overall reaction rate, the activation parameters involving $\Delta \mathrm{G}^{\#}, \Delta \mathrm{S}^{\#}$ and $\Delta \mathrm{H}^{\#}$ could be now calculated for the first step (rate determining step), as an elementary reaction, on the basis of Eyring equation. The results are reported in Table 11.

\section{Further kinetic investigations}

Effect of structure of dialkyl acetylenedicarboxylates: To confirm the above observations, further experiments were performed with diethyl acetylenedicarboxylate $\mathbf{2} \mathbf{b}$ and dimethyl acetylenedicarboxylate $\mathbf{2 a}$, respectively, under the same conditions used in the previous experiments. The values of the second-order rate constant $\left(k_{2}\right)$ for the reactions between $(\mathbf{1}, \mathbf{2 b}$ and $\mathbf{3})$ and $(\mathbf{1}, \mathbf{2 a}$ and 3) are reported in Table 10 for all solvents and temperatures investigated. The original experimental absorbance curves (dotted line) accompanied by the second order fit curves (full line), which exactly fit experimental curves (dotted line) confirm the previous observations again for both reactions at $12.0^{\circ} \mathrm{C}$ and $303 \mathrm{~nm}$.

As can be seen from Tables 10 and 11, the behavior of diethyl acetylenedicarboxylate $\mathbf{2} \mathbf{b}$ and dimethyl acetylenedicarboxylate $\mathbf{2 a}$ is the same as for the di-tert-butyl acetylenedicarboxylate 2c with respect to the reaction with triphenylphosphine $\mathbf{1}$ and methyl carbamate $\mathbf{3}$. The rate of the former reactions was also accelerated in a higher dielectric constant environment and with higher temperatures; however, these rates under the same condition are approximately 7.50-6.30 times greater than for the reaction with di-tert-butyl acetylenedicarboxylate 2c. It seems that both inductive and steric factors for the bulky alkyl groups in 2c tend to reduce the overall reaction rate (see equation 9). In the case of dimethyl acetylenedicarboxylate $\mathbf{2 a}$, the lower steric and inductive effects of the dimethyl groups exert a powerful effect on the rate of reaction. As can be seen from table $\mathbf{4}$, enthalpy of activation $\left(\Delta \mathrm{H}^{\#}\right)$ considerably increases on going from $\mathbf{4 a}$ or $\mathbf{4 b}$ to 4c. Significantly negative value of the entropy of activation $\left(\Delta S^{\#}\right)$ suggests that the transition state is more ordered than the starting reactants. In the presence of $\mathbf{2 a}$ and $\mathbf{2} \mathbf{b}$, the transition state 
is more ordered than that in the presence of 2c. More negative value of entropy of activation $\left(\Delta \mathrm{S}^{\#}\right)$ is accompanied by a decrease in the enthalpy of activation $\left(\Delta H^{\#}\right)$. Decrease in $\Delta S^{\#}$ and increase in $\Delta \mathrm{H}^{\#}$ values are more sizeable on going from $\mathbf{4 a}$ or $\mathbf{4 b}$ to $\mathbf{4 c}$. Results indicate that the strict factor of the bulky alkyl groups in $\mathbf{2 c}$ plays more important role than its inductive effect.

Table 11. The activation parameters involving $\mathrm{Ea}, \Delta \mathrm{G}^{\#}, \Delta \mathrm{S}^{\#}$ and $\Delta \mathrm{H}^{\#}$ for the reactions between $(\mathbf{1}, \mathbf{2 a}$ and 3$),(\mathbf{1}, \mathbf{2 b}$ and $\mathbf{3})$ and $(\mathbf{1 , 2 c}$ and 3$)$ at $12.0^{\circ} \mathrm{C}$

\begin{tabular}{|c|c|c|c|c|c|}
\hline Reactions & Solvent & $\begin{array}{c}\mathrm{Ea} \\
\left(\mathrm{kJ} \cdot \mathrm{mol}^{-1}\right)\end{array}$ & $\begin{array}{c}\Delta \mathrm{G}^{\#} \\
\left(\mathrm{~kJ} . \mathrm{mol}^{-1}\right)\end{array}$ & $\begin{array}{c}\Delta \mathrm{H}^{\#} \\
\left(\mathrm{~kJ} \cdot \mathrm{mol}^{-1}\right)\end{array}$ & $\begin{array}{c}\Delta \mathrm{S}^{\#} \\
\left(\mathrm{~J} \cdot \mathrm{mol}^{-1} \cdot \mathrm{K}^{-1}\right)\end{array}$ \\
\hline \multirow{2}{*}{ 1, 2a and $\mathbf{3}$} & 1,2-dichloroethane & $14.1 \pm 0.7$ & $67.0 \pm 1.8$ & $11.7 \pm 1.1$ & $-189.1 \pm 4.1$ \\
\hline & ethyl acetate & $15.4 \pm 0.9$ & $67.2 \pm 2.2$ & $13.0 \pm 1.7$ & $-185.1 \pm 5.0$ \\
\hline \multirow{2}{*}{$1,2 b$ and 3} & 1,2-dichloroethane & $16.7 \pm 1.6$ & $67.8 \pm 2.0$ & $14.2 \pm 1.0$ & $-183.1 \pm 5.0$ \\
\hline & ethyl acetate & $23.0 \pm 1.9$ & $68.6 \pm 1.6$ & $20.6 \pm 1.2$ & $-164.2 \pm 5.2$ \\
\hline \multirow[b]{2}{*}{$1,2 c$ and 3} & 1,2-dichloroethane & $41.6 \pm 1.7$ & $70.5 \pm 2.3$ & $39.2 \pm 2.0$ & $-107.0 \pm 4.7$ \\
\hline & ethyl acetate & $43.5 \pm 1.5$ & $70.7 \pm 2.1$ & $41.0 \pm 2.0$ & $-101.5 \pm 4.9$ \\
\hline
\end{tabular}

\section{Conclusions}

In conclusion, we have prepared novel phosphorus ylides using a one-pot reaction between triphenylphosphine, dialkyl acetylenedicarboxylates and methyl carbamate. The assignment of the $E$ - and Z-isomers as a major or minor form in both the ylides $\mathbf{4 a}$ and $\mathbf{4 b}$ were undertaken by AIM and NPA methods and also CHelpG keyword. Quantum mechanical calculations clarified how the ylides $\mathbf{4 a}$ and $\mathbf{4 b}$ exist in solution as a mixture of the two major $((Z)-\mathbf{4 a},(Z)-\mathbf{4 b})$ and minor $((E)-\mathbf{4 a},(E)-\mathbf{4 b})$ geometrical isomers, respectively. In addition, NMR studies on the basis of theoretical calculations were employed for the assignment of two major (Z)-4a and minor $(E)$ 4a geometrical isomers. The results are compatible with the experimental data from the ${ }^{1} \mathrm{H},{ }^{13} \mathrm{C}$ and ${ }^{13} \mathrm{P}$ NMR spectroscopy. In addition, kinetic investigation of these reactions was undertaken using UV spectrophotometry. The results can be summarized as follows: (1) the appropriate wavelengths and concentrations were determined to follow the reaction kinetics. (2) The overall reaction order followed second-order kinetics and the reaction orders with respect to triphenylphosphine, dialkyl acetylenedicarboxylate and methyl carbamate were one, one and zero respectively. (3) The rates of all reactions were accelerated at higher temperatures. Under the same conditions, the activation energy and activation enthalpy for the reaction with di-tertbutyl acetylenedicarboxylate $\mathbf{2 c}$ was higher than that for the both reactions which were followed 
by the diethyl acetylenedicarboxylate $\mathbf{2 b}$ and dimethyl acetylenedicarboxylate $\mathbf{2 a}$ in all solvent and temperature investigated (4) The rates of all reactions were increased in solvent of higher dielectric constant and this can be related to differences in stabilization by the solvent of the reactants and the activated complex in the transition state. (5) Increased steric bulk in the alkyl groups of the dialkyl acetylenedicarboxylates, accompanied by the correspondingly greater inductive effect, reduced the overall reaction rate. (6) With respect to the experimental data, the first step of the proposed mechanism was recognized as a rate-determining step $\left(k_{2}\right)$ and this was confirmed based upon the steady-state approximation. Also, the third step was identified as a fast $\operatorname{step}\left(k_{3}\right)$.

\section{Experimental Section}

General. Melting points, IR and UV spectra of all compounds were measured on an electro thermal 9100 apparatus, a Shimadzu IR-460 spectrometer and a Cary UV/Vis spectrophotometer model Bio-300 with a $10 \mathrm{~mm}$ light-path quartz spectrophotometer cell throughout the current work, respectively. The ${ }^{1} \mathrm{H},{ }^{31} \mathrm{P}$, and ${ }^{13} \mathrm{C}$ NMR spectra were recorded on a Bruker DRX-500 Avance instrument in $\mathrm{CDCl}_{3}$ as solvent at 500.1, 202.5 and $125.8 \mathrm{MHz}$, respectively. The mass spectra were recorded on a GCMS-QP5050A mass spectrometer operating at an ionization potential of $70 \mathrm{eV}$. Elemental analysis for $\mathrm{C}, \mathrm{H}$ and $\mathrm{N}$ was performed using a Heraeus CHN-ORapid analyzer. Methyl carbamate, dialkyl acetylenedicarboxylates and triphenylphosphine were purchased from Fluka, and used without further purification. All extra pure solvents including 1,2-dichloroethane, ethyl acetate and THF were obtained from Merck (Darmstadt, Germany). Quantum mechanical calculations were performed using Gaussian03 and AIM2000 program packages.

Synthesis of the ylides 4. General procedures. To a magnetically stirred solution of triphenylphosphine $(0.26 \mathrm{~g}, 1 \mathrm{mmol})$ and methyl carbamate $(0.75 \mathrm{~g}, 1 \mathrm{mmol})$ in acetone $(10 \mathrm{ml})$, was added dropwise, a mixture of dimethyl acetylenedicarboxylate $(0.14 \mathrm{~g}, 1 \mathrm{mmol})$ in of acetone $(3 \mathrm{ml})$ at $-5^{\circ} \mathrm{C}$ over $10 \mathrm{~min}$. After a few minutes stirring at room temperature, the solid phase was filtered, washed with cold diethyl ether $(3 \times 5 \mathrm{ml})$ and recrystallized from acetone. A cream powder was obtained as a final product $(0.44 \mathrm{~g}$, yield $92 \%)$ m.p $158-160{ }^{\circ} \mathrm{C}$, IR $(\mathrm{KBr})$ $\left(v_{\max }, \mathrm{cm}^{-1}\right): 1725,1640$ and $1615(3 \mathrm{C}=\mathrm{O}) . \mathrm{MS}(\mathrm{m} / \mathrm{z}, \%): 448(\mathrm{M}-\mathrm{OMe}, 26), 420\left(\mathrm{M}-\mathrm{CO}_{2} \mathrm{Me}\right.$, 43), $361\left(\mathrm{M}-2 \mathrm{CO}_{2} \mathrm{Me}, 38\right), 262\left(\mathrm{PPh}_{3}, 100\right), 183\left(\mathrm{PPh}_{2}, 59\right), 108(\mathrm{PPh}, 62), 77$ (Ph, 23$), 74$ $\left(\mathrm{C}_{2} \mathrm{H}_{4} \mathrm{NO}_{2}\right.$, 14). Anal.Calcd. for $\mathrm{C}_{26} \mathrm{H}_{26} \mathrm{NO}_{6} \mathrm{P}$ (479.20): C, 65.11; H, 5.47; N, $2.92 \%$. Found: C, $65.20 ; \mathrm{H}, 5.42 ; \mathrm{N}, 2.98 \%$.

Dimethyl-2-(methyl carbamoyl)-3-(triphenylphosphanylidene)-butanedioate (4a). Major isomer. (Z)-4a (65\%): ${ }^{1} \mathrm{H} \mathrm{NMR}\left(500.1 \mathrm{MHz}, \mathrm{CDCl}_{3}\right): \delta 3.15,3.61$ and $3.72(9 \mathrm{H}, 3 \mathrm{~s}, 3 \mathrm{OCH})$, $4.27\left(1 \mathrm{H}_{\text {bro }}, \mathrm{P}=\mathrm{C}-\mathrm{CH}-\mathrm{NH}\right), 6.58\left(1 \mathrm{H}, \mathrm{d},{ }^{3} J_{\mathrm{HH}} 9.2 \mathrm{~Hz}, \mathrm{P}=\mathrm{C}-\mathrm{CH}-\mathrm{NH}\right), 7.29-7.73\left(15 \mathrm{H}_{\text {arom }}, \mathrm{m}\right.$, $\left.3 \mathrm{C}_{6} \mathrm{H}_{5}\right) .{ }^{13} \mathrm{C}$ NMR $\left(125.8 \mathrm{MHz}, \mathrm{CDCl}_{3}\right): \delta 43.06\left(\mathrm{~d},{ }^{1} J_{\mathrm{PC}} 125.5 \mathrm{~Hz}, \mathrm{P}=C\right), 48.84,51.69$ and 52.11 
$\left(3 \mathrm{~s}, 3 \mathrm{OCH}_{3}\right), 53.66\left(\mathrm{~d},{ }^{2} J_{\mathrm{PC}} 17.2 \mathrm{~Hz}, \mathrm{P}=\mathrm{C}-\mathrm{CH}\right), 126.58\left(\mathrm{~d},{ }^{1} J_{\mathrm{PC}} 92.3 \mathrm{~Hz}, \mathrm{C}_{\mathrm{ipso}}\right), 128.50\left(\mathrm{~d},{ }^{3} J_{\mathrm{PC}}\right.$ $\left.12.3 \mathrm{~Hz}, \mathrm{C}_{\text {meta }}\right), 131.96$ (d, $\left.{ }^{4} J_{\mathrm{PC}} 2.5 \mathrm{~Hz}, \mathrm{C}_{\mathrm{para}}\right), 133.65$ (d, $\left.{ }^{2} J_{\mathrm{PC}} 9.9 \mathrm{~Hz}, \mathrm{C}_{\text {ortho }}\right), 156.45(\mathrm{C}=\mathrm{O})$, $169.95\left(\mathrm{~d},{ }^{3} J_{\mathrm{PC}} 10.9 \mathrm{~Hz}, \mathrm{C}=\mathrm{O}\right.$ ester), $173.76\left(\mathrm{~d},{ }^{2} J_{\mathrm{PC}} 8.7 \mathrm{~Hz}, \mathrm{P}-\mathrm{C}=C\right) .{ }^{31} \mathrm{P} \mathrm{NMR}(202.5 \mathrm{MHz}$, $\left.\mathrm{CDCl}_{3}\right): \delta 21.89\left(\mathrm{Ph}_{3} \mathrm{P}^{+}-\mathrm{C}\right)$.

Minor isomer: (E)-4a (35\%): ${ }^{1} \mathrm{H} \mathrm{NMR}\left(500.1 \mathrm{MHz}, \mathrm{CDCl}_{3}\right): \delta 3.56,3.63$ and $3.68(9 \mathrm{H}, 3 \mathrm{~s}$, $\left.3 \mathrm{OCH}_{3}\right), 4.27\left(1 \mathrm{H}_{\text {bro }}, \mathrm{P}=\mathrm{C}-\mathrm{CH}-\mathrm{NH}\right), 5.93\left(1 \mathrm{H}, \mathrm{d},{ }^{3} J_{\mathrm{HH}} 8.8 \mathrm{~Hz}, \mathrm{P}=\mathrm{C}-\mathrm{CH}-\mathrm{NH}\right), 7.29-7.73\left(15 \mathrm{H}_{\text {arom }}\right.$, $\left.\mathrm{m}, 3 \mathrm{C}_{6} \mathrm{H}_{5}\right) .{ }^{13} \mathrm{C} \mathrm{NMR}\left(125.8 \mathrm{MHz}, \mathrm{CDCl}_{3}\right): \delta 43.57\left(\mathrm{~d},{ }^{1} J_{\mathrm{PC}} 137.2 \mathrm{~Hz}, \mathrm{P}=C\right), 49.92,51.69$ and $52.11\left(3 \mathrm{~s}, 3 \mathrm{OCH}_{3}\right), 52.94\left(\mathrm{~d},{ }^{2} J_{\mathrm{PC}} 17.9 \mathrm{~Hz}, \mathrm{P}=\mathrm{C}-\mathrm{CH}\right), 125.97\left(\mathrm{~d},{ }^{1} J_{\mathrm{PC}} 92.6 \mathrm{~Hz}, \mathrm{C}_{\mathrm{ipso}}\right), 128.60(\mathrm{~d}$, $\left.{ }^{3} J_{\mathrm{PC}} 12.2 \mathrm{~Hz}, \mathrm{C}_{\text {meta }}\right), 131.96\left(\mathrm{~d},{ }^{4} J_{\mathrm{PC}} 2.5 \mathrm{~Hz}, \mathrm{C}_{\mathrm{para}}\right), 133.65$ (d, $\left.{ }^{2} J_{\mathrm{PC}} 9.9 \mathrm{~Hz}, \mathrm{C}_{\text {ortho }}\right), 156.40(\mathrm{C}=\mathrm{O})$, $169.95\left(\mathrm{~d},{ }^{3} J_{\mathrm{PC}} 10.9 \mathrm{~Hz}, \mathrm{C}=\mathrm{O}\right.$ ester$), 173.76\left(\mathrm{~d},{ }^{2} J_{\mathrm{PC}} 8.7 \mathrm{~Hz}, \mathrm{P}-\mathrm{C}=C\right) .{ }^{31} \mathrm{P} \mathrm{NMR}(202.5 \mathrm{MHz}$, $\left.\mathrm{CDCl}_{3}\right): \delta 22.88\left(\mathrm{Ph}_{3} \mathrm{P}^{+}-\mathrm{C}\right)$.

Diethyl 2-(methylcarbamoyl)-3-(triphenylphosphanylidene)-butanedioate (4b). White powder, $0.46 \mathrm{~g}$, yield 90\%,m.p 143-145 ${ }^{\circ} \mathrm{C}$, IR (KBr) $\left(v_{\max }, \mathrm{cm}^{-1}\right): 1720,1660$ and 1620

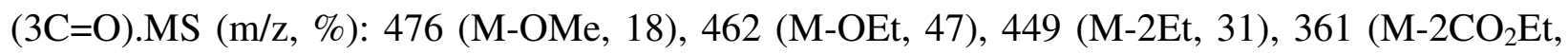
25), $262\left(\mathrm{PPh}_{3}, 75\right), 183\left(\mathrm{PPh}_{2}, 54\right), 108(\mathrm{PPh}, 100), 77$ (Ph, 82). Anal.Calcd. for $\mathrm{C}_{28} \mathrm{H}_{30} \mathrm{NO}_{6} \mathrm{P}$ (507.23): C, 66.24; H, 5.96; N, $2.76 \%$. Found: C, 66.31; H, 6.02; N, $2.81 \%$.

Major isomer: $(Z)-4 b(70 \%):{ }^{1} \mathrm{H}$ NMR $\left(500.1 \mathrm{~Hz}, \mathrm{CDCl}_{3}\right) \delta 0.46$ and $1.24\left(6 \mathrm{H}, 2 \mathrm{t},{ }^{3} J_{\mathrm{HH}} 7.1 \mathrm{~Hz}\right.$, $\left.2 \mathrm{OCH}_{2} \mathrm{CH}_{3}\right), 3.60\left(3 \mathrm{H}, \mathrm{s}, \mathrm{OCH}_{3}\right), 4.15\left(4 \mathrm{H}, \mathrm{m}, 2 \mathrm{ABX}\right.$ system, $\left.2 \mathrm{OCH}_{2} \mathrm{CH}_{3}\right), 4.25(1 \mathrm{H}$ bro, $\mathrm{P}=\mathrm{C}-$ $\mathrm{CH}-\mathrm{NH}), 6.59\left(1 \mathrm{H}, \mathrm{d},{ }^{3} \mathrm{~J}_{\mathrm{HH}} 9.3 \mathrm{~Hz}, \mathrm{P}=\mathrm{C}-\mathrm{CH}-\mathrm{NH}\right), 7.48-7.75\left(15 \mathrm{H}_{\text {arom }}, \mathrm{m}, 3 \mathrm{C}_{6} \mathrm{H}_{5}\right) .{ }^{13} \mathrm{C} \mathrm{NMR}$ $\left(125.8 \mathrm{MHz} \mathrm{CDCl}_{3}\right): \delta 13.83$ and $14.13\left(2 \mathrm{~s}, 2 \mathrm{OCH}_{2} \mathrm{CH}_{3}\right), 42.78\left(\mathrm{~d},{ }^{1} \mathrm{~J}_{\mathrm{PC}} 127.7 \mathrm{~Hz}, \mathrm{P}=C\right), 51.68$ $\left(\mathrm{OCH}_{3}\right), 53.64\left(\mathrm{~d},{ }^{2} J_{\mathrm{PC}} 17.9 \mathrm{~Hz}, \mathrm{P}=\mathrm{C}-\mathrm{CH}\right), 57.41$ and $60.91\left(2 \mathrm{~s}, 2 \mathrm{OCH}_{2} \mathrm{CH}_{3}\right), 126.20\left(\mathrm{~d},{ }^{1} J_{\mathrm{PC}}\right.$ $\left.92.4 \mathrm{~Hz}, \mathrm{C}_{\mathrm{ipso}}\right), 128.44$ (d, $\left.{ }^{3} J_{\mathrm{PC}} 12.6 \mathrm{~Hz}, \mathrm{C}_{\text {meta }}\right), 131.95\left(\mathrm{C}_{\mathrm{para}}\right), 133.78$ (d, $\left.{ }^{2} J_{\mathrm{PC}} 9.7 \mathrm{~Hz}, \mathrm{C}_{\text {ortho }}\right)$, $156.60(\mathrm{C}=\mathrm{O}), 169.54\left(\mathrm{~d},{ }^{3} \mathrm{~J}_{\mathrm{PC}} 12.2 \mathrm{~Hz}, \mathrm{C}=\mathrm{O}\right), 173.16\left(\mathrm{~d},{ }^{2} \mathrm{~J}_{\mathrm{PC}} 9.0 \mathrm{~Hz}, \mathrm{P}-\mathrm{C}=C\right) .{ }^{31} \mathrm{P}$ NMR $(202.5$ $\left.\mathrm{MHz}, \mathrm{CDCl}_{3}\right): \delta 21.92\left(\mathrm{Ph}_{3} \mathrm{P}^{+}-\mathrm{C}\right)$.

Minor isomer: (E)-4b (30\%): ${ }^{1} \mathrm{H} \mathrm{NMR}\left(500.1 \mathrm{MHz}, \mathrm{CDCl}_{3}\right): \delta 1.20$ and $1.29\left(6 \mathrm{H} .2 \mathrm{t} .{ }^{3} J_{\mathrm{HH}} 7.0\right.$, $\left.2 \mathrm{OCH}_{2} \mathrm{CH}_{3}\right), 3.64\left(3 \mathrm{H}, \mathrm{s}, \mathrm{OCH}_{3}\right), 4.08\left(4 \mathrm{H}, \mathrm{m}, 2 \mathrm{ABX}\right.$ system, $\left.2 \mathrm{OCH}_{2} \mathrm{CH}_{3}\right), 4.25\left(1 \mathrm{H}_{\text {bro }}, \mathrm{P}=\mathrm{C}-\right.$ $\mathrm{C} H-\mathrm{NH}), 5.96\left(1 \mathrm{H}, \mathrm{d},{ }^{3} \mathrm{~J}_{\mathrm{HH}} 8.2 \mathrm{~Hz}, \mathrm{P}=\mathrm{C}-\mathrm{CH}-\mathrm{N} H\right), 7.49-7.75\left(15 \mathrm{H}_{\text {arom }}, \mathrm{m}, 3 \mathrm{C}_{6} \mathrm{H}_{5}\right) .{ }^{13} \mathrm{C} \mathrm{NMR}$ $\left(125.8 \mathrm{MHz}, \mathrm{CDCl}_{3}\right): \delta 14.18$ and $14.92\left(2 \mathrm{OCH}_{2} \mathrm{CH}_{3}\right), 43.97\left(\mathrm{~d},{ }^{1} J_{\mathrm{PC}} 135.9 \mathrm{~Hz}, \mathrm{P}=C\right), 51.80$ $\left(\mathrm{OCH}_{3}\right), 53.05\left(\mathrm{~d},{ }^{2} J_{\mathrm{PC}} 17.9 \mathrm{~Hz}, \mathrm{P}=\mathrm{C}-\mathrm{CH}\right), 58.06$ and $60.91\left(2 \mathrm{OCH}_{2} \mathrm{CH}_{3}\right), 126.85\left(\mathrm{~d},{ }^{1} J_{\mathrm{PC}} 92.1\right.$ $\mathrm{Hz}, \mathrm{C}_{\text {ipso }}$ ), 128.55 (d, ${ }^{3} J_{\mathrm{PC}} 14.8 \mathrm{~Hz}, \mathrm{C}_{\text {meta }}$ ), 131.95 ( $\left.\mathrm{C}_{\text {para }}\right), 133.78$ (d, $\left.{ }^{2} J_{\mathrm{PC}} 9.7 \mathrm{~Hz}, \mathrm{C}_{\text {ortho }}\right), 156.20$ $(\mathrm{C}=\mathrm{O}), 169.54\left(\mathrm{~d},{ }^{3} J_{\mathrm{PC}} 12.2 \mathrm{~Hz}, \mathrm{C}=\mathrm{O}\right), 173.16\left(\mathrm{~d},{ }^{2} J_{\mathrm{PC}} 9.0 \mathrm{~Hz}, \mathrm{P}-\mathrm{C}=C\right),{ }^{31} \mathrm{P} \mathrm{NMR}(202.5 \mathrm{MHz}$, $\left.\mathrm{CDCl}_{3}\right): \delta 22.82\left(\mathrm{Ph}_{3} \mathrm{P}^{+}-\mathrm{C}\right)$.

\section{Acknowledgements}

Authors sincerely thank the University of Sistan and Baluchestan, Payam Noor University, and the Islamic Azad University of Bardsir, for providing financial support for this work. 


\section{References}

1. Cadogan, J. I. G. Organophosphorus Reagents in Organic Synthesis; Academic Press: New York, 1979.

2. Hudson, H. R. Primary, Secondary and Tertiary Phosphines, Polyphosphines and Heterocyclic Organophosphorus Compounds, in the Chemistry of Organophosphorus Compounds; Hantley, F. R. Ed.; 1990; Vol. 1, Wiley; New York, pp. 386-472.

3. Yavari, I.; Anary-Abbasinejad, M.; Hossaini, Z. Org. Biomol. Chem. 2003, 1, 560. http://dx.doi.org/10.1039/b210263n

PMid:12926260

4. Mazurkiewicz, R.; Kuznik, A.; Grymel, M.; Pazdzierniok-Holewa, A. Arkivoc 2007, (vi), 193.

\section{http://dx.doi.org/10.3998/ark.5550190.0008.614}

5. Heydari, R.; Hazeri, N.; Maghsoodlou, M.T.; Habibi-Khorassani, S.M.; Barahuie, F.; Marandi, G. Arkivoc 2009, 7, 86.

6. Jayashree, P.; Shanthi, G.; Perumal. P. T. Synlett 2009, 6, 917.

7. Kazemian, M.A.; Nassiri, M.; Ebrahimi, A.; Maghsoodlou, M.T.; Habibi-Khorassani, S.M.; Vasheghani-Farahani, F. Arkivoc 2008, 17, 173.

8. Allen, D. W. Organophosphorus Chem. 2008, 37, 13. http://dx.doi.org/10.1039/b704637p

9. Anaraki-Ardakani, H.; Mosslemin, M.H.; Anary-Abbasinejad, M.; Mirhosseini, S.H.; Shams, N. Arkivoc 2010, 11, 343.

http://dx.doi.org/10.3998/ark.5550190.0011.b27

10. Heydari, R.; Khaksar, S.; Tajbakhsh, M. Tetrahedron Lett. 2009, 50, 77. http://dx.doi.org/10.1016/j.tetlet.2008.10.106

11. Hazeri, N.; Habibi-Khorasani, S. M.; Maghsoodlou, M. T.; Marandi, G.; Nassiri, M.; GhulameShahzadeh, A. J. Chem. Res. 2006, 215.

12. Maghsoodlou, M. T.; Habibi-Khorasani, S. M.; Hazeri, N.; Nassiri, M.; Kakaei, R.; Marandi, G. Phosphorus, Sulfur and Silicon 2006, 181, 553. http://dx.doi.org/10.1080/10426500500267624

13. Aminkhani, A.; Kabiri, R.; Habibi-Khorasani, S. M.; Heydari, R.; Maghsoodlou, M. T.; Marandi, G.; Lashkari, M.; Rostamizadeh, M. Sulfur Chemistry 2009, 30, 500. http://dx.doi.org/10.1080/17415990902839450

14. Maghsoodlou, M. T.; Hazeri, N.; Habibi-Khorasani, S. M.; Heydari, R.; Marandi, G.; Lashkari, M.; Bagherpour, Kh.; Gharechaei, Z. Monatsh. Chem. 2010, 141, 351. http://dx.doi.org/10.1007/s00706-010-0266-8

15. Reed, A. E.; Weinstock, R. B.; Weinhold, F. J. J. Chem. Phys. 1985, 83, 735.

16. Frisch, M. J. Gaussian 98, Revision A. 7, Gaussian, Inc., Pittsburg h, PA, 1998.

17. Bader, R. F. W. Atoms in Molecules: A Quantum Theory; Oxford University: New York, 1990. 
18. BieglerKönig, F. W.; Schönbohm, J.; Bayles, D. J. Comput. Chem. 2001, 22, 545.

http://dx.doi.org/10.1002/1096-987X(20010415)22:5<545::AID-JCC1027>3.0.CO;2-Y

19. Grabowski, S. J. J. Mol. Struct. 2001, 562, 137.

http://dx.doi.org/10.1016/S0022-2860(00)00863-2

20. Arnold, W. D.; Oldfield, E. J. Am. Chem. Soc. 2000, 122, 12835.

http://dx.doi.org/10.1021/ja0025705

21. Rozas, I.; Alkorta, I.; Elguero, J. J. Am. Chem. Soc. 2000, 122, 11154.

http://dx.doi.org/10.1021/ja0017864

22. Schwartz, L. M.; Gelb, R. I. Anal. Chem. 1978, 50, 1592.

http://dx.doi.org/10.1021/ac50033a055 